УДК 543.613.2+556.142

(C) 2012

Сененко Н. Б., кандидат фізико-математичних наук,

Романович I. С., студент *, Санжаревська О. I., студент

Полтавський національний технічний університет ім. Юрія Кондратюка

Чала Н. В., аспірант **

Полтавська державна аграрна академія

\title{
ДОСЛІДЖЕННЯ ВМІСТУ ЗАБРУДНЮЮЧИХ РЕЧОВИН ІРУНТУ ТА ГРУНТОВОЇ ВОДИ с. ІВАНІВКА КАРЛІВСЬКОГО РАЙОНУ ПОЛТАВСЬКОЇ ОБЛАСТІ
}

\section{Рецензент - доктор технічних наук, професор В. О. Бондар}

Виконано комплексне дослідження проби трунту й визначено основні фізико-хімічні показники проб води централізованого та децентралізованого водопостачання, відібраних у с. Іванівка Карлівського району Полтавської області. Стан трунту визначений як деградований сірозем, щуо потребує регулярного внесення органічних добрив. Виконаний аналіз впливу водорозчинної складової трунту на даний водоносний горизонт. Виявлена невідповідність якості води иентралізованого водопостачання фізіологічній потребі людини, а води децентралізованого водопостачання - нормативам Держ.Сан.ПіНу.

Ключові слова: фізико-хімічні показники, трунт, децентралізоване водопостачання, органолептичні показники, нітрат-іони, загальна твердість, вміст водорозчинних солей, санітарні норми.

Постановка проблеми. Головною метою сучасного розвитку суспільства є забезпечення гармонії та стабільності взаємодії соціальної й екологічної систем. Техногенне навантаження згубно впливає на навколишнє середовище, поскільки чимало промислових підприємств викидають в атмосферу, грунт і воду неконтрольовані кількості шкідливих домішок. Особливістю Полтавської області є активний розвиток газовидобувного комплексу, який для буріння та інтенсифікації роботи свердловин використовує величезну кількість хімічних реагентів. Вони, в свою чергу, потрапляють у підземні водоносні горизонти, з якими, на жаль, шкідливі домішки мігрують на великі відстані. Значної шкоди водним ресурсам області (як і в більшості областей України) наносять побутові стоки з поверхні во- дозабору, стоки промислових підприємств, неконтрольоване i нераціональне використання пестицидів, гербіцидів, мінеральних добрив тощо. Поскільки населення сільської місцевості Полтавщини використовує 3 питною метою воду децентралізованого водопостачання (а вона в більшості випадків не відповідає нормативам якості), то останнім часом зросла кількість захворювань і смертність саме серед сільського населення. Негативну роль відіграє й недостатня інформованість про токсичний вплив на організм людини шкідливих домішок у воді. Споживачі оцінюють органолептичні показники, а підвищений вміст нітрат-іонів жодним чином не погіршує їх, тому вкрай нелегко переконати людей не використовувати таку воду з питною метою. Саме через це в сільській місцевості склалася катастрофічна ситуація із забезпеченням населення якісною питною водою.

Аналіз основних досліджень і публікацій, у яких започатковано розв'язання проблеми. Перше місце 3-поміж причин смертності населення сільської місцевості Полтавщини посідають захворювання серцево-судинної системи, основними причинами яких $\epsilon$ вживання води незадовільної якості [3]. Причиною такого стану води $\epsilon$, перш за все, чимала кількість відходів, що накопичилися в області, надмірне використання азотних добрив, - усі солі нітратної та нітритної кислот (нітрати та нітрити відповідно) розчинні у воді, мігрують водоносними горизонтами на значні відстані, накопичуються у городині $[2,3,7,12,16]$. Найбільшу загрозу для людей і тварин становлять рослини, вирощені на грунтах, насичених нітратними добривами [2].

* Керівник - кандидат фізико-математичних наук Н. Б. Сененко

** Керівник - доктор сільськогосподарських наук, професор П. В. Писаренко 
Найбільш чутливі до надлишку нітратів діти перших місяців життя. Якщо мами вживають високонітратні овочі, - нітрати потрапляють у грудне молоко. В організмі матері існує механізм захисту від нітратів, але можливості його обмежені. Крім того високонітратні продукти за систематичного їх вживання викликають так звану безсимптомну метгемоглобінемію [2]. Проблема невідповідності води децентралізованого водопостачання сільської місцевості Полтавської області нормативам головного документу якості [8] нітрат-іонами є надзвичайно актуальною, поскільки немає жодного населеного пункту із питною водою належної якості [3].

Мета роботи - виконати комплексне дослідження проби грунту, провести аналіз можливого впливу водорозчинної складової грунту на водоносний горизонт, експериментально визначити основні фізико-хімічні показники якості питної води даного водоносного горизонту; виявити вміст забруднюючих речовин у ній, зробити висновки про наявність токсичного впливу на організм людини.

Матеріали і методи досліджень. У ході роботи нами було експериментально визначено основні фізико-хімічні показники проб грунту та чотирьох проб води, відібраних у с. Іванівка Карлівського району Полтавської області [11, 13-15]. Грунт інтенсивно використовується населенням із сільськогосподарською метою, а воду децентралізованого водопостачання вживають як питну. Під час комплексного дослідження грунту, згідно [1], ми визначили гігроскопічну вологість грунту термостатичним і гідростатичним методами, вологоємність, щільність, обмінну кислотність, вміст органічних речовин, $\mathrm{pH}$ водної витяжки, втрати маси при прожарюванні, вміст водорозчинних солей у водній витяжці грунту, визначили пї макрокомпонентний склад. Окрім того провели якісний аналіз водної витяжки грунту з метою виявлення токсичних домішок і виконали кореляційний аналіз одержаних результатів. Проби води були відібрані:

проба № 1 - вода централізованого постачання (глибина свердловини 500 м) 1 км від відбору проби грунту;

проба № 2 - децентралізована вода шахтного колодязя глибиною 10 м, 100 м від відбору проби грунту;

проба № 3 - децентралізована вода (свердловина глибиною 11 м), що знаходиться на відстані 900 м від місця забору № 2;

проба № 4 - вода шахтного колодязя глибиною 7 м, що знаходиться в одному місці 3 водо- забором № 2 .

У процесі дослідження проб води, згідно 3 [4, $5,6,9,10]$, ми визначили органолептичні показники, основні фізико-хімічні показники та макрокомпонентний склад, порівняли одержані значення із санітарно-допустимими нормами. Провели порівняльний аналіз складу грунтової витяжки та питної води.

Результати досліджень. Результати експериментального дослідження грунту представлені у таблиці 1.

Грунт є досить ущільненим, що впливає на його текстуру, макро-, мезо- та мікроструктури, на газообмін, на сорбційні властивості й обмінні процеси.

Вологоємність має середнє значення. Вміст органічних речовин досить низький. Варто зауважити, що теоретично вміст органічних речовин у грунті може становити близько 20 \%, а гумусова складова близько 80-90 \% від загального вмісту органічних речовин, або до 16-18 \% від складу грунту. Деградація грунтів Полтавської області, як і України в цілому, відбувається такими значними темпами, що те значення, яке ми визначили $(4,12 \%)$, с достатнім порівняно зі станом грунтів області в районах відбирання проб. Відповідно зі значенням вмісту органічних речовин корелює й низьке значення обмінної кислотності: $\mathrm{pH} \epsilon$ слаболужним і повністю відповідає макрокомпонентному складу водної витяжки грунту.

Ми виконали повний якісний і кількісний аналіз водної витяжки грунту. Були виявлені нітратіони та іони трьохвалентного заліза, тому ми визначили їх вміст кількісно. Їх вміст незначний, але присутність цих іонів свідчить про існування джерел надходження. Вміст заліза значно перевищує санітарно допустимі норми для води питного призначення, тоді як вміст нітрат-іонів задовольняє нормі, що є досить позитивним результатом для Полтавщини, бо відомі факти забруднення грунтових вод нітрат-іонами [3].

Ми перерахували вміст іонів натрію і сульфатіонів та паралельно визначили вміст сульфатіонів ваговим методом. Одержали відтворюваність результатів.

Експериментально одержані результати досліджень питної води представлені у таблиці 2.

За органолептичними показниками всі проби відповідають нормі. За загальною жорсткістю пробу води №2 шахтного колодязя не можна вживати 3 питною метою. Після кип'ятіння значення жорсткості знижується до межі норми, але ця проба №2 непридатна до вживання 3 питною 
метою за вмістом загального заліза. Проби №2, №3, №4 містять достатньо високу кількість нітрат-іонів, що свідчить про джерело їх надходження. В цих пробах виявлений підвищений вміст водорозчинних солей, що є також непри- пустимим.

У цілому вода централізованого водопостачання відповідає нормам Держ.Сан.ПіН, але не задовольняє фізіологічні потреби людини.

\section{1. Основні фізико-хімічні показники трунту}

\begin{tabular}{|c|c|}
\hline Показник & 3начення \\
\hline Вологість (термостатний метод), \% & 4,15 \\
\hline Вологість (гідростатичний метод), $\%$ & 4,00 \\
\hline Вміст кристалізаційної води, \% & 5,35 \\
\hline Вологоємність, \% & 45,85 \\
\hline Вміст органічних речовин , \% & 4,12 \\
\hline Вміст гумусу, \% & 3,71 \\
\hline Вміст втрат маси при прожарюванні & 13,62 \\
та вміст мінеральної частини, \% & 86,38 \\
\hline Значення обмінної кислотності (на 100 г грунту) мг/мекв & $1,51 / 0,151$ \\
\hline рН водної витяжки грунту & 7,23 \\
\hline Загальний вміст водорозчинних солей, мг & 109,40 \\
\hline Загальний вміст гідрокарбонат іонів (на 100 г грунту) мг/мекв & $43,70 / 0,72$ \\
\hline Загальний вміст хлорид-іонів (на 100 г грунту) мг/мекв & $16,91 / 0,48$ \\
\hline Загальний вміст іонів кальцію & $12,00 / 0,59$ \\
та магнію (на 100 г грунту) мг/мекв & $8,80 / 0,72$ \\
\hline Загальний вміст іонів натрію (на 100 г грунту) мг/мекв & $6,22 / 0,27$ \\
\hline Загальний вміст сульфат-іонів (на 100 г грунту) мг/мекв & $13,61 / 0,43$ \\
\hline Загальний вміст нітрат-іонів (на 100 г грунту) [мг/л]/мекв & $1,05 / 0,017$ \\
\hline Загальний вміст іонів-заліза (на 100 г грунту) [мг/л]/мекв & $1,19 / 0,021$ \\
\hline
\end{tabular}

\section{2. Основні фізико-хімічні показники якості питної води}

\begin{tabular}{|c|c|c|c|c|c|}
\hline Показники & $\begin{array}{c}\text { Проба } \\
\text { № 1 }\end{array}$ & $\begin{array}{c}\text { Проба } \\
\text { № 2 }\end{array}$ & $\begin{array}{c}\text { Проба } \\
\text { № 3 }\end{array}$ & $\begin{array}{c}\text { Проба } \\
\text { № 4 }\end{array}$ & Норма \\
\hline 1 & 2 & 3 & 4 & 5 & 6 \\
\hline Вміст нітрат-іонів, мг/г & 0,5 & 10,5 & 9,900 & 9,800 & $<11,3$ \\
\hline $\begin{array}{c}\text { Вміст загального заліза, } \\
\text { мг/л }\end{array}$ & 0,06 & 0,8 & 0,080 & 0,130 & $<0,3$ \\
\hline $\begin{array}{c}\text { Загальна жорсткість, } \\
\text { мекв/л }\end{array}$ & 0,618 & 12,998 & 4,705 & 6,305 & $<7$ \\
\hline $\begin{array}{c}\text { Жорсткість магнієва, } \\
\text { мекв/л }\end{array}$ & 0,238 & 8,055 & 2,716 & 3,492 & $0,86-6,59$ \\
\hline $\begin{array}{c}\text { Жорсткість кальцієва, } \\
\text { мекв/л }\end{array}$ & 0,380 & 4,943 & 1,989 & 2,813 & $1,5-4$ \\
\hline Лужність, мекв/л & 6,000 & 6,200 & 3,300 & 4,200 & $1,5-6,5$ \\
\hline рН & 6,800 & 8,100 & 7,800 & 7,900 & $6,5-8,5$ \\
\hline $\begin{array}{c}\text { Вміст водорозчинних } \\
\text { солей, мг/л }\end{array}$ & 59,000 & 2878 & 1195 & 1719 & $<100$ \\
\hline Запах, бал & 1 & 1 & 1 & 1 & $<2$ \\
\hline Колірність, бал & 4 & 5 & 5 & 5 & $<20$ \\
\hline Присмак, бал & 1 & 2 & 1 & 1 & $<2$ \\
\hline Вміст іонів алюмінію, мг/л & - & 1,43 & - & - & $<0,5$ \\
\hline
\end{tabular}




\section{Висновки:}

1. Грунт є незасоленим, що надзвичайно позитивно для засолених грунтів Полтавської обласTi.

2. Стан грунту можна охарактеризувати як деградований, такий що потребує регулярного внесення органічних добрив і рекультивації.

3. Водорозчинна складова грунту містить нітрат-іони, кількість яких перевищує допустимі норми у воді.

4. Існує вплив водорозчинної складової грунту на стан води водоносного горизонту.

5. Вода децентралізованого водопостачання

\section{БІБЛІОГРАФІЯ}

1. Бирюков Н. С. Методическое пособие по определению физико-химических свойств грунтов / Н. С. Бирюков, В. Д. Казарновский, Ю. Л. Мотылёв. - М. : Недра, 1975. - 177 с.

2. Вредные вещества в промышлености / М. В. Лазарев // Справочник для химиков. В трех томах. Т. III. - Л. : Химия, 1977. - 608 с.

3. Голік Ю. С. Екологічна бібліотека Полтавщини / Ю. С. Голік, О. Е. Ілляш. - Випуск 1. - Полтава: Полтавський літератор, 2004. - 166 с.

4. ГОСТ 3351-74. Вода питьевая. Методы определения вкуса, запаха, цветности, мутности. М. : Издательство стандартов, 1975. - 169 с.

5. ГОСТ 4011-72. Вода питьевая. Методы определения общего железа. - М. : Издательство стандартов, 1982. - 9 с.

6. ГОСТ 18826-73. Колориметрический метод определения нитратов с сульфосалициловым натрием. - М.: Издательство стандартов, 1974. - 8 с.

7. Дорогунияов С. I. Природні ресурси: екологоекономічна оцінка / С. І. Дорогунцов, А. М. Муховиков, М. А. Хвесик. - К. : Кондор, 2004. - 291 с. 8. ДСПіН. Вода питна. Гігієнічні вимоги до якості води господарчо-питного централізованого водопостачання. - К., 1999. - 20 с.

9. ДСТУ ISO 6058:2003 (ISO 6058-1984, ЮТ). Визначення кальцію. Титрометричний метод iз застосуванням етилендіамінтетраоцтової кислоти. - К., 2004. -6 с. непридатна для вживання 3 питною метою, iii слід використовувати в технічних цілях.

6. Воду з глибини 500 м можна вживати з питною метою.

7. Використання досліджуваного грунту із сільськогосподарською метою та вживання води децентралізованого водопостачання можуть стати чинниками захворювання населення.

8. Стан грунту і води децентралізованого водопостачання потребують уваги з боку адміністрації району, санітарних служб щодо створення охоронних заходів.

10. ДСТУ ISO 6059:2003 (ISO 6059-1984, ЮТ). Визначення сумарного вмісту кальцію та магнію. Титрометричний метод із застосуванням етилендіамінтетраоцтової кислоти. - К., 2004 - 6 с.

11. ДСТУ 10.3.81-6-2001. Якість грунту. Відбір проб. - К. : Держспоживстандарт України, 2002. $-17 \mathrm{c}$.

12. Коваленко О. М. Нітрат-нітритна проблема та шляхи іï вирішення / О. М. Коваленко, А. І. Горобець, А. М. Кучук // Науч. зап. Харьковского института экологии и социальной защиты. - X., 2002. - T. 2. - C. 3-13.

13. НСУ ДСТУ ISO 5667-1:2003. Якість води. Відбирання проб. Частина 1. Постанови щодо проекту програм проведення відбирання проб. К. : Держспоживстандарт України, 2004. - 17 с.

14. НСУ ДСТУ ISO 5667-2:2003. Якість води. Відбирання проб. - Частина 2. Постанови щодо методів відбирання проб. - К. : Держспоживстандарт України, 2004. - 9 с.

15. НСУ ДСТУ ISO 5667-11:2006. Якість води. Відбирання проб. - Частина 1. Постанови щодо відбирання проб підземних вод. - К. : Держспоживстандарт України, 2007. - 11 с.

16. Яuик A. B. Водне господарство в Україні / А. В. Яцик. - К. : Генеза, 2000. -456 с. 